\title{
KAJIAN EMPIRIS ATAS PERILAKU BELAJAR, KECERDASAN \\ EMOSIONAL, EFIKASI DIRI TERHADAP STRES KULIAH \\ MAHASISWA AKUNTANSI PADA UNIVERSITAS \\ DI DAERAH ISTIMEWA YOGYAKARTA
}

\author{
Toni Nur Wijanarko \\ Kurniawan Ali Fachrudin
}

\begin{abstract}
Learning behavior, emotional intelligence and self-efficacy is a trait that is on the individual in achieving success. This research study repair Marita et al (2007), in his research stated behavioral variables affect learning and emotional intelligence to the stress of college. This study adds efficacy variables influencing stress in college. This research was conducted with the aim of analyzing whether there is influence learning behavior, emotional intelligence and self-efficacy accounting students against college stress. This study is a survey research on accounting students in Yogyakarta Special Region. The population in this study were students in accounting at the University of DIY and using convenience sampling sample criteria. In this study, using a sample of 294 students. Analysis of the indigenous is used factor analysis, multiple regression, F-test and t-test. The results showed behavioral variables studied, emotional intelligence and selfefficacy variables affect the college stress.
\end{abstract}

Keywords: behavioral learning, emotional intelligence, self-efficacy and stress of college.

\section{PENDAHULUAN}

Globalisasi seringkali menimbulkan banyak problematika dalam kehidupan. Selain itu, tuntutan dalam perkuliahan atau pembelajaran yang ada di perguruan tinggi tidak jarang membuat stres pada mahasiswa. Peneliti menganggap bahwa stres kuliah yang terjadi pada mahasiswa adalah dikarenakan pada kurangnya kesadaran mahasiswa akan pola pembelajaran yang berbeda, hal itu tentu nantinya akan berpengaruh pada pandangan dan sikap yang akan diambil pada mahasiswa itu sendiri.

Setiap mahasiswa pasti mempunyai harapan-harapan tentang masa depan yang akan mereka jalani. Disisi lain, tuntutan-tuntutan untuk sukses hidup dalam segala bidang pasti menjadi bayangan dalam setiap pikiran mereka. Bayangan 
untuk mencapai kesuksesan karir, kesuksesan memperoleh pekerjaan yang sesuai, kesuksesan kebahagiaan dalam hidup, dan kesuksesan dalam mencapai IPK yang maksimal seringkali membayangi setiap langkahnya untuk mencapai keinginan. Akan tetapi, seringkali keinginan yang sudah dibayangkan oleh individu tidak sesuai dengan harapan. Pemicunya bisa bermacam-macam mulai dari ketidakmampuan, lingkungan yang tidak mendukung dan cara belajar yang salah. Lingkungan perkuliahan tentu juga akan berbeda terutama semenjak mahasiswa tersebut mulai berada di semester akhir. Tuntutan akan tugas-tugas dan tekanan untuk cepat mencapai kelulusan dengan IPK yang sesuai keinginan menjadi pemicu stres mahasiswa. Stres merupakan segala hal yang pernah dirasakan oleh seluruh manusia sehat. Stres yang banyak dirasakan mahasiswa antara lain adalah kejenuhan dalam perkuliahan dan faktor permasalahan lain yang mahasiswa itu belum bisa menyelesaikannya.

Saryanti (2010) dalam penelitiannya menyatakan bahwa pada dasarnya ada dua faktor yang menyebabkan stres pada mahasiswa itu, yaitu faktor dari dalam (intern) dan faktor dari luar (ekstern). Faktor dari dalam mahasiswa lebih pada pribadi individu mahasiswa tersebut. Contohnya, rasa malas, rasa kurangnya kegigihan, kemauan pada mahasiswa, kecerdasan yang dimiliki oleh individu mahasiswa tersebut dan kepercayaan diri (efikasi diri) yang dimiliki oleh mahasiswa. Faktor dari luar, mahasiswa lebih pada keterkaitan individu itu terhadap lingkungan, terhadap teman-teman, terhadap dosen, terhadap orang tua, terhadap lingkungan sosialnya. Penelitian ini memfokuskan pada faktor-faktor dari dalam mahasiswa yang di dalamnya antara lain perilaku belajar, kecerdasan emosional dan efikasi diri. Perilaku belajar menyangkut mahasiswa dalam menjalankan pola pembelajaran di perkuliahan. Perilaku belajar ini mencakup intensitas mahasiswa membaca buku, mengisi waktu luang, intensitas keperpustakaan, dan langkah yang ditempuh mahasiswa dalam menentukan jalur pembelajarannya untuk mencapai tujuan yang akan dicapai. Kebiasaan belajar mahasiswa erat kaitannya dengan penggunaan waktu, baik untuk belajar maupun untuk kegiatan lain yang menunjang 
belajar. Belajar yang efisien dapat dicapai apabila menggunakan strategi yang tepat, yaitu dengan mengatur waktu antara saat mengikuti kuliah, belajar di rumah, belajar bersama, dan kebiasaan untuk menghadapi ujian. Dorongan untuk membiasakan belajar dengan baik perlu diberikan karena akan mengarah pada suatu pembentukan sikap dalam bertindak (Afifah, 2004: 3 dalam Patmasari 2010).

Efikasi diri merupakan faktor intern yang sudah pasti ada dalam diri mahasiswa dalam menghadapi segala permasalahan yang dihadapinya. Tingkat kepercayaan diri mahasiswa akan menentukan mereka dalam memunculkan solusi pada setiap permasalahan yang dihadapi. Efikasi diri juga merupakan hal yang mempengaruhi mahasiswa dalam menghadapi dan mengelola stres. Kecerdasan emosional juga merupakan faktor yang terpenting dalam pengelolaan stres pada diri mahasiswa. Penelitian ini mengacu pada penelitian yang sudah dilakukan Marita dkk. (2007) yang meneliti tentang kajian empiris atas perilaku belajar dan kecerdasan emosional dalam mempengaruhi stres kuliah mahasiswa akuntansi. Selain itu, pada penelitian Astuti (2011) yang meneliti tentang pengaruh perilaku belajar, kecerdasan emosional dan kecerdasan spiritual terhadap stres mahasiswa akuntansi di Universitas Ahmad Dahlan. Penelitian Patmasari (2012) juga menjadi bahan acuan dalam penelitian ini, yang meneliti tentang pengaruh perilaku belajar, kecerdasan emosional, kecerdasan spiritual dan efikasi diri terhadap stres kuliah mahasiswa akuntansi di Universitas Ahmad Dahlan. Alasan peneliti tertarik dengan penelitian ini karena ingin mengetahui apakah terdapat perbedaan hasil penelitian dengan penelitian yang pernah dilakukan dahulu dengan penelitian yang akan dilakukan saat ini.

Penelitian ini menggunakan sampel yang hampir sama dengan penelitan yang dilakukan oleh Marita dkk. (2007) yaitu mahasiswa akuntansi yang menempuh pendidikan pada universitas di D.I. Yogyakarta dan terdapat penambahan variabel dari penelitian sebelumnya. Variabel yang di tambahkan dari penelitian sebelumnya adalah variabel efikasi diri. Sampel yang digunakan dalam penelitian ini adalah mahasiswa akuntansi semester akhir karena menurut penelitian sebelumnya hal 
yang sering membuat stres adalah ketika mulai berada pada semester akhir. Berdasarkan latar belakang yang telah diutarakan sebelumnya, peneliti tertarik untuk melakukan penelitian mengenai kajian empiris atas perilaku belajar, kecerdasan emosional, efikasi diri terhadap stres kuliah mahasiswa akuntansi pada universitas di Daerah Istimewa Yogyakarta.

\section{LANDASAN TEORI DAN PENGEMBANGAN HIPOTESIS}

\section{Perilaku Belajar}

Ahmadi (1993) dalam Hanifah dan Syukriy (2001) lebih jauh menyatakan bahwa belajar adalah suatu perubahan di dalam diri manusia, sehingga apabila setelah belajar tidak terjadi perubahan dalam diri manusia, maka tidak dapat dikatakan padanya telah berlangsung proses belajar. Menurut Giyono (1993) dalam Marita dkk (2007) kebiasaan belajar dapat berlangsung melalui tiga cara yaitu: memperoleh reinforcement, classical, conditioning. Surachmad dalam Saryanti (2012), mengatakan ada lima hal yang berhubungan dengan perilaku belajar yang baik, yaitu: kebiasaan mengikuti pelajaran, kebiasaan memantapkan pelajaran, kebiasaan membaca buku, kebiasaan menyiapkan karya tulis, dan kebiasaan menghadapi ujian.

\section{Kecerdasan Emosional.}

Goleman (2003) mengungkapkan kecerdasan emosional merujuk pada kemampuan mengenali perasaan kita sendiri dan perasaan orang lain, kemampuan memotivasi diri sendiri, dan kemampuan mengelola emosi dengan baik pada diri sendiri serta hubungannya bersama orang lain. Kecerdasan emosional adalah kemampuan merasakan, memahami dan secara selektif menerapkan daya dan kepekaan emosi sebagai sumber energi dan pengaruh yang manusiawi (Cooper dan Sawaf dalam Saryanti, 2010). Goleman, (2003: 34) mengungkapkan lima wilayah kecerdasan emosional yang dapat menjadi pedoman bagi individu untuk mencapai kesuksesan kehidupan sehari-hari, yaitu: (1) mengenali diri, (2) mengelola emosi, (3) memotivasi diri, (4) mengenali emosi orang lain, (5) membina hubungan 
dengan orang lain.

\section{Efikasi Diri}

Bandura (1997) dalam Saryanti (2010) mengatakan efikasi diri adalah pengembangan subjektif individu terhadap kemampuannya untuk menyusun tindakan yang dibutuhkan untuk menyelesaikan tugas-tugas khusus yang dihadapi. Efikasi diri tidak berkaitan langsung dengan kecakapan yang dimiliki individu melainkan pada penilaian diri tentang apa yang dapat dilakukan, tanpa terkait kecakapan yang dimiliki. Menurut Luthans (2008: 205) dalam Azizah (2011), bahwa efikasi diri secara langsung dapat mempengaruhi tiga hal, di antaranya:

a) Pemilihan perilaku, yaitu keputusan akan dibuat atas dasar betapa ampuhnya seseorang merasa terhadap pilihan, misalnya dalam penugasan kerja atau bahkan bidang karir.

b) Usaha motivasi, yaitu orang yang akan mencoba lebih keras dan memberikan banyak usaha pada tugas, individu memiliki efikasi diri yang lebih tinggi akan berbeda daripada individu dengan penilaian kemampuan rendah.

c) Keteguhan, yaitu orang dengan efikasi diri tinggi akan bertahan ketika menghadapi masalah atau bahkan gagal, sedangkan orang yang efikasi rendah cenderung akan menyerah ketika ada hambatan muncul.

Bandura dalam Saryanti (2010) mengungkapkan bahwa perbedaan efikasi diri pada setiap individu terletak pada tiga komponen, yaitu magnitude, strength, dan generality.

\section{Stres Kuliah}

Stres adalah keadaan individu yang kurang merasakan suatu kebebasan dalam jiwa, kurang nyaman, kurang tenang, cenderung mengalami ketegangan, serta kurang dapat merasakan kebahagiaan. Individu tersebut merasakan tekanan dalam kehidupan sehari-hari yang dapat mempengaruhi kesehatan atau sakit (Greenberg 2002).

Ivianchevic dan Martinson (1993) dalam Yulianti (2002) mendefinisi stres 
secara sederhana sebagai interaksi individu dengan angkatan. Stres adalah suatu kondisi ketegangan yang mempengaruhi emosi, proses berfikir dan kondisi seseorang. Stres kuliah lebih ditekankan pada pola pikir dan tanggapan individu dalam menanggapi setiap masalah, menghadapi setiap tekanan. Stres kuliah adalah kondisi dimana seseorang mahasiswa tersebut tidak mampu untuk menetralisir kondisi atau keadaan, sehingga individu tersebut tidak mampu fokus dalam belajarnya.

\section{METODA PENELITIAN}

\section{Populasi dan Sampel}

Populasi dalam penelitian ini adalah mahasiswa akuntansi semester 4 sampai 8 pada universitas yang terdapat di wilayah D.I.Yogyakarta. Sampel dalam penelitian ini adalah mahasiswa akuntansi semester 4 sampai 8 di wilayah D.I.Yogyakarta. Sampel diambil secara acak dengan persebaran kuesioner pada universitas. Data pada penelitian ini adalah data primer, yaitu sumber data yang langsung memberikan data kepada pengumpul data (Sugiyono, 2011). Data primer berupa hasil perolehan data jawaban kuesioner dari mahasiswa akuntansi pada universitas di D.I. Yogyakarta. Pengambilan kuesioner dilakukan secara langsung dengan mendatangi responden, yaitu semua mahasiswa akuntansi yang ada pada universitas di D.I Yogyakarta yang menempuh kuliah semester 4 sampai 8.

\section{Definisi Operasional dan Pengukuran Variabel.}

\section{Perilaku Belajar}

Perilaku belajar serangkaian kebiasaan yang ada pada diri mahasiswa atau individu sehingga dapat menimbulkan perubahan dalam diri individu tersebut. Indikator yang digunakan antara lain kebiasaan mengikuti pelajaran, kebiasaan membaca buku, kunjungan ke perpustakaan, dan kebiasaan menghadapi ujian yang diukur dengan menggunakan 5 skala Likert yaitu 1) sangat tidak setuju, 2) tidak setuju, 3) netral, 4) setuju, dan 5) sangat setuju. 


\section{Kecerdasan Emosional}

Kecerdasan emosional merupakan kemampuan seseorang mampu mengendalikan emosi dalam dirinya, kecerdasan emosional meliputi kemampuan seseorang atau individu mengenali dirinya, pengendalian dirinya, memotivasi dirinya, empati yang dimilikinya, dan kemampuan sosialnya. Skala pengukuran dalam penelitian ini menggunakan skala likert lima poin yaitu: 1) sangat tidak setuju, 2) tidak setuju, 3) netral, 4) setuju, dan 5) sangat setuju.

\section{Efikasi diri}

Efikasi diri merupakan salah satu kemampuan pada individu untuk menganalisis setiap permasalahan secara cepat dan memutuskan hal yang akan dilakukan dengan pertimbangan yang matang sehingga dalam setiap langkah perjalanannya akan bisa termotivasi oleh dirinya sendiri. Penelitian ini menggunakan 5 skala Likert yaitu: 1) sangat tidak setuju, 2) tidak setuju, 3) netral, 4) setuju, dan 5) sangat setuju.

\section{Stres Kuliah}

Stres kuliah merupakan keadaan mahasiswa mengalami tekanan yang melebihi kapasitas kemampuan pikiran individu tersebut, sehingga ia tidak mampu untuk berkonsentrasi dan dalam belajarnya terganggu. Indikator yang digunakan adalah kebosanan dalam kuliah, orang tua, konflik antar teman mahasiswa, hubungan pribadi, hubungan dengan dosen. Indikator ini akan diukur menggunakan 5 skala Likert yaitu: 1) sangat setuju, 2) setuju, 3) tidak pasti atau netral, 4) tidak setuju, dan 5)sangat tidak setuju. Urutan setuju atau tidak setuju dapat juga dibalik mulai dari sangat tidak setuju sampai sangat setuju (Indriantoro \& Supomo, 1999: 104).

\section{Metoda Analisis Data}

Metoda analisis data yang digunakan dalam penelitian ini adalah analisis regresi linier berganda. Hal ini digunakan untuk mengetahui pengaruh perilaku 
belajar, efikasi diri, kecerdasan emosional terhadap stres kuliah. Model persamaannya adalah sebagai berikut:

$$
\mathrm{Y}=b_{0}+b_{1} \mathrm{X}_{1}+b_{2} \mathrm{X}_{2}+b_{3}+b_{3} \mathrm{X}_{3}+e
$$

Keterangan:

$$
\begin{aligned}
& \text { bo } \\
& \mathrm{X}_{1} \\
& =\text { Konstanta } \\
& =\text { Perilaku belajar } \\
& \mathrm{X}_{2} \\
& =\text { Efikasi diri } \\
& \mathrm{X}_{3} \\
& =\text { Kecerdasan emosional } \\
& \text { Y } \\
& =\text { Stres kuliah } \\
& =\text { Koefisien regresi untuk } \mathrm{X}_{1}, \mathrm{X}_{2} \text { dan } \mathrm{X}_{3}
\end{aligned}
$$

\section{Uji Kualitas Data}

\section{Uji Validitas}

Pengujian validitas dalam penelitian ini menggunakan validitas konstruk (construct validity) yaitu konsep pengukuran validitas dengan cara menguji suatu instrumen untuk mengukur construct sesuai dengan yang diharapkan (Indriantoro \& Supomo, 1998: 184). Pengujian validitas ini menggunakan analisis faktor konfirmatori untuk menguji konstruk mempunyai undimensionalitas.

\section{Uji Reliabilitas}

Reliabilitas merupakan ukuran suatu kestabilan dan konsistensi responden dalam menjawab hal yang berkaitan dengan construct pertanyaan yang merupakan dimensi suatu variabel dan disusun dalam bentuk suatu kuesioner (Sujarweni, 2007: 187). Pengukuran reliabilitas dalam penelitian ini menggunakan coefficient cronbach's alpha. Suatu construct atau variabel dikatakan reliabel jika memberikan nilai cronbach alpha > 0,60 (Nunnally, 1960 dalam Ghozali, 2006). 


\section{Uji Asumsi Klasik}

\section{Uji Normalitas}

Uji normalitas yang digunakan dalam penelitian ini yaitu uji KolmogorovSmirnov yang terdapat pada program komputer SPSS. Tujuannya adalah menguji model regresi variabel pengganggu atau residual memiliki distribusi normal. Pengambilan keputusan dilakukan dengan membandingkan signifikansi hasil pengujian dengan tingkat signifikansi dari uji normalitas ini sebesar 0,05. Artinya jika nilai Sighit > 0,05 maka distribusi adalah normal (asimetris) (Ghozali, 2006).

\section{Uji Multikolinieritas}

Uji multikolinieritas bertujuan untuk menguji model analisis regresi ditemukan adanya pengaruh antarvariabel bebas (independen). Model regresi yang baik seharusnya tidak terjadi korelasi di antara variabel bebas. Ada tidaknya multikolinieritas di dalam regresi dapat dilihat dari: (1) tolerance value, (2) nilai variance inflation factor (VIF). Model regresi yang bebas multikolinieritas adalah yang mempunyai nilai toleransi di atas 0,1 atau VIF di bawah 10. Jika tolerance variance di bawah 0,1 atau VIF di atas 10, maka terjadi multikolinieritas (Ghozali, 2006).

\section{Uji Autokorelasi}

Uji autokorelasi bertujuan untuk menguji ada tidaknya korelasi antara kesalahan pengganggu pada perioda $\mathrm{t}$ dengan $\mathrm{t}-1$ pada persamaan regresi linear. Pengujian gejala autokorelasi dilakukan dengan uji Durbin-Watson (Ghozali, 2006). 
Tabel 1

Dasar pengambilan keputusan ada tidaknya autokorelasi

\begin{tabular}{|l|l|l|}
\hline \multicolumn{1}{|c|}{ Hipotesis nol } & \multicolumn{1}{|c|}{ Keputusan } & \multicolumn{1}{c|}{ Jika } \\
\hline Tidak ada autokorelasi positif & Tolak & $0<\mathrm{d}<\mathrm{dl}$ \\
Tidak ada autokorelasi positif & No decision & $\mathrm{dl}<\mathrm{d}<\mathrm{du}$ \\
Tidak ada korelasi negatif & Tolak & $4-\mathrm{dl}<\mathrm{d}<4$ \\
Tidak ada korelasi nigatif & No decision & $4-\mathrm{du} \leq \mathrm{d} \leq 4-\mathrm{dl}$ \\
Tidak ada autokorelasi, positif atau negatif & Tidak di tolak & $\mathrm{dl}<\mathrm{d}<4-\mathrm{du}$ \\
\hline
\end{tabular}

Sumber: Imam Ghozali 2006 : 99-100

\section{Uji Heteroskedastisitas}

Heteroskedastisitas dapat diuji dengan menggunakan uji Glejser. Cara untuk mendeteksi ada atau tidaknya heteroskedastisitas yaitu menggunakan uji Glejser. Uji Glejser dilakukan dengan meregres nilai absolut residual terhadap variabel independen. Jika hasil uji Glejser menunjukkan tidak ada satupun variabel independen yang signifikansinya di atas 5\%, maka dapat disimpulkan model regresi tidak mengandung adanya heteroskedastisitas (Ghozali, 2006).

\section{Pengujian Hipotesis}

Koefisien determinasi $\left(\mathrm{R}^{2}\right)$ digunakan untuk mengukur kemampuan model dalam menerangkan variasi variabel independen. Penelitian ini menggunakan adjusted $\mathrm{R}^{2}$ karena agar tidak terjadi adanya bias dalam jumlah variabel independen yang dimasukkan ke dalam model. Nilai adjusted $\mathrm{R}^{2}$ berkisar antara 0 dan 1 , artinya jika nilai adjusted $\mathrm{R}^{2}$ semakin mendekati 1 maka semakin baik kemampuan model tersebut dalam menjelaskan variabel dependen (Ghozali 2006: 87).

Uji t digunakan untuk menunjukkan pengaruh variabel independen (X1, X2, X3) dalam menerangkan variasi variabel dependen (Y). Pengujian dilakukan dengan menggunakan significance level 0,05 ( $\alpha=5 \%)$. Apabila nilai signifikansi $\mathrm{t}<$ 0,05 maka Ha diterima, berarti terdapat pengaruh antara satu variabel independen terhadap variabel dependen. Apabila nilai signifikansi t > 0,05 maka Ha ditolak, berarti tidak berhasil mendukung $\mathrm{Ha}$, berarti tidak ada pengaruh antara variabel independen terhadap variabel dependen (Ghozali, 2006). 
Uji $\mathrm{F}$ dilakukan untuk mengetahui terdapat pengaruh atau tidak antara variabel independen terhadap variabel dependen. Dasar pengambilan keputusan apabila nilai probability (F-statistic) $<0,05$ atau 5\%. Maka dapat disimpulkan bahwa minimal satu variabel independen berpengaruh terhadap variabel dependen atau Ha diterima. Jika nilai probability ( $\mathrm{F}$-statistic) $>0,05$ atau 5\%, maka dapat disimpulkan bahwa semua variabel independen tidak berpengaruh terhadap variabel dependen (Ghozali, 2006).

\section{HASIL DAN PEMBAHASAN}

\section{Analisis Karakteristik Responden}

Populasi dari penelitian ini adalah semua mahasiswa akuntansi semester 4 sampai 8 yang menempuh studi pada universitas yang ada di D. I. Yogyakarta. Teknik yang digunakan pengambilan sampel adalah melalui penyebaran kuesioner pada universitas di D. I. Yogyakarta. Daftar universitas yang diambil datanya untuk penelitian ini: Universitas Mercubuana (UMB), Universitas Janabadra (UJB), Universitas Pembangunan "Veteran" Yogyakarta (UPN), Universitas Muhammadiyah Yogyakarta (UMY), Universitas Negeri Yogyakarta (UNY), Universitas Gadjah Mada (UGM), Universitas PGRI Yogyakarta (UPY), Universitas Sarjanawiyata Tamansiswa (UST), Universitas Islam Indonesia (UII), Universitas Atma Jaya (UAJ), Universitas Kristen Duta Wacana (UKDW), Universitas Ahmad Dahlan (UAD). Jumlah kuesioner yang disebar adalah 330. Kuesioner yang dapat diolah adalah 294 kuesioner, karena 36 kuesioner dinyatakan gugur dan selebihnya tidak kembali.

\section{Hasil Uji Kualitas Data}

Hasil pengujian menunjukkan dari pengujian analisis faktor, untuk menunjukkan validitas data, nilai yang diharapkan adalah angka pada setiap komponen diambil >0,5. Sehingga didapati dari 15 pertanyaan pada perilaku belajar terdapat 5 pertanyaan yang memiliki data valid. Variabel kecerdasan emosional dari 25 pertanyaan terdapat 6 pertanyaan yang valid. Variabel efikasi diri 
dari 11 pertanyaan semua dinyatakan valid. Sedangkan variabel stres kuliah juga menunjukkan bahwa semua pertanyaan valid.

Hasil pengujian reliabilitas data menunjukkan bahwa cronbach alpha pada prediktor perilaku belajar, kecerdasan emosional, efikasi diri, dan stres kuliah lebih besar dari 0,60 ini berarti setiap prediktor atau setiap variabel dinyatakan reliabel.

\section{Hasil Uji Asumsi Klasik}

\section{Uji Normalitas}

Tabel 2

Hasil Uji Normalitas

\begin{tabular}{|l|r|}
\hline \multicolumn{2}{|l|}{ One-Sample Kolmogorov-Smirnov Test } \\
\hline Kolmogorov-Smirnov Z & 0.502 \\
\hline Asymp. Sig. (2-tailed) & 0.962 \\
\hline
\end{tabular}

Sumber: Data Primer 2013

Tabel 2 menunjukkan bahwa nilai signifikansi residual lebih besar dari 0,05 yaitu sebesar 0,962, sehingga variabel yang digunakan mempunyai residual yang berdistribusi normal.

\section{Uji Multikolinieritas}

\section{Tabel 3}

Uji Multikolinearitas

\begin{tabular}{|c|l|l|}
\hline \multicolumn{2}{|c|}{ Model } & VIF \\
\hline \multirow{3}{*}{1} & (Constant) & \\
\cline { 2 - 3 } 1 & Perilaku Belajar & 5,481 \\
\cline { 2 - 3 } & Kecerdasan Emosional & 5,508 \\
\cline { 2 - 3 } & Efikasi Diri & 1,017 \\
\hline
\end{tabular}

Sumber: Data primer, diolah 2013

Berdasar tabel 3, VIF terjadi diantara 1 sampai 10. Ini membuktikan bahwa variabel perilaku belajar, kecerdasan emosional, dan efikasi diri terbebas dari multikolinearitas, yaitu masing masing sebesar 5,481; 5,508 dan 1,017. 


\section{Uji Heterokedastisitas}

Tabel 4

Uji Heterokedastisitas

\begin{tabular}{|c|l|l|l|}
\hline \multicolumn{2}{|l|}{ Model } & Sig. & Keterangan \\
\hline & (Constant) & 0.454 & Bebas \\
\hline & Perilaku Belajar & 0.479 & Bebas \\
\hline & Kecerdasan Emosional & 0.234 & Bebas \\
\hline & Efikasi Diri & 0.198 & Bebas \\
\hline
\end{tabular}

Sumber: Data primer, diolah 2013

Tabel 4 menunjukkan bahwa model regresi tersebut tidak terjadi heteroskedatisitas, karena nilai signifikansinya di atas $5 \%$ atau 0,05 .

\section{Uji Autokorelasi}

\section{Tabel 5}

Hasil Uji Autokorelasi

\begin{tabular}{|l|c|}
\hline Model & Durbin-Watson \\
\hline 1 & 1,797 \\
\hline
\end{tabular}

Sumber: Data primer, diolah 2013

Tabel 5 menunjukkan bahwa nilai Durbin-Watson sebesar 1,797. Nilai tabel Durbin-Watson dengan signifikansi 5\% dan jumlah responden 294, menunjukkan nilai $d l$ sebesar 1,795 dan nilai $d u$ sebesar 1,822. Maka dapat disimpulkan tidak terjadi autokorelasi dengan dasar bahwa, nilai $d l<d<4-d u$.

\section{ANALISIS REGRESI BERGANDA}

\section{Koefisien Regresi Berganda}

Hasil analisis regresi berganda dapat dilihat sebagai berikut:

$$
\mathrm{SK}=9,976-0,063 \mathrm{~PB}+0,053 \mathrm{KE}+0,069 \mathrm{ED}+e
$$

Persamaan tersebut dapat dijelaskan sebagai berikut:

a. Konstanta sebesar 9,976 hal ini memberikan arti bahwa jika tidak terdapat sifat perilaku belajar, kecerdasan emosional dan efikasi diri maka stres kuliah bernilai positif 9,976 . 
b. Nilai $b_{1}$ sebesar - 0,063 mengandung arti bahwa setiap kali variabel perilaku belajar bertambah satu satuan maka rata-rata variabel stres kuliah berkurang 0,063 .

c. Nilai $b_{2}$ sebesar 0,053 mengandung arti bahwa setiap variabel kecerdasan emosional bertambah satu satuan maka rata-rata variabel stres kuliah bertambah 0,053 .

d. Nilai $b_{3}$ sebesar 0,069 mengandung arti bahwa setiap variabel efikasi diri bertambah satu satuan maka nilai rata-rata variabel stres kuliah bertambah 0,069 .

\section{Pengujian Hipotesis}

\section{Uji Koefisien Determinasi $\left(\mathbf{R}^{2}\right)$}

\section{Tabel 6}

\section{Hasil Analisis Uji Koefisien Determinasi $\left(\mathbf{R}^{2}\right)$}

\begin{tabular}{|l|c|}
\hline Model & Adjusted $R$ Square \\
\hline 1 &, 058 \\
\hline
\end{tabular}

Sumber: Data primer, diolah 2013

Hasil pengujian menunjukkan koefisiensi determinasi yang telah disesuaikan $\left(\mathrm{R}^{2}\right)$ atau $\mathrm{R}$ Square yaitu 0,058 yang berarti 5,8\% perubahan variabel Y (stres kuliah) disebabkan oleh variabel X1, X2, X3. Sisanya 94,2\% disebabkan oleh variabel bebas lainnya yang tidak diamati.

\section{Uji F}

Tabel 7

Hasil Analisis Uji

\begin{tabular}{|c|l|l|l|}
\hline \multicolumn{2}{|l|}{ Model } & F & Sig. \\
\hline \multirow{3}{*}{1} & Regression & & \\
\cline { 2 - 2 } & Residual & \multirow{2}{*}{25,201} &, $000^{\mathrm{b}}$ \\
\cline { 2 - 2 } & Total & & \\
\hline
\end{tabular}

Sumber: Data primer, diolah 2013 
Berdasar tabel 7, dapat dianalisis bahwa pengujian dilakukan dengan menggunakan signifikansi level 0,05 ( $\alpha=5 \%$ ). Jika nilai signifikansi $\mathrm{F}<0,05$ maka H0 ditolak atau Ha diterima, yang berarti koefisien regresi signifikan. Artinya terdapat pengaruh antara semua variabel independen terhadap variabel dependen. Hasil dari pengujian tersebut diperoleh nilai signifikansi 0,000 atau $<0,05$ ini berarti bahwa variabel perilaku belajar, kecerdasan emosional, efikasi diri berpengaruh terhadap stres kuliah mahasiswa akuntansi pada universitas di D. I. Yogyakarta.

Uji $t-t e s t$

Tabel 8

Hasil Analisis Uji-t

\begin{tabular}{|l|l|l|l|}
\hline \multicolumn{2}{|l|}{ Model } & t & Sig. \\
\hline \multirow{4}{*}{1} & Constant) & 7,932 &, 000 \\
\cline { 2 - 4 } & Perilaku Belajar & $-2,306$ &, 022 \\
\cline { 2 - 4 } & Kecerdasan Emosional & 2,911 &, 004 \\
\cline { 2 - 4 } & Efikasi Diri & 2,534 &, 012 \\
\hline
\end{tabular}

Sumber: Data primer 2013

\section{Pengaruh Perilaku Belajar terhadap Stres Kuliah}

Nilai signifikansi t untuk variabel perilaku belajar sebesar 0,022. Perilaku belajar yang mengacu pada kebiasaan membaca buku, kunjungan keperpustakaan dan kebiasaan dalam menghadapi ujian memberikan pengaruh terhadap stres kuliah akuntansi, ini sesuai dengan pernyataan pada umumnya perilaku belajar dapat mempengaruhi stres kuliah.

\section{Pengaruh Kecerdasan Emosional terhadap Stres Kuliah}

Nilai signifikansi t untuk variabel kecerdasan emosional sebesar 0,04. Kecerdasan emosional yang mencakup empati, kemampuan mengenali perasaan sendiri, kemampuan memotivasi diri ternyata dalam penelitian ini berpengaruh terhadap stres kuliah akuntansi. Berarti mereka menganggap bahwa kecerdasan emosional merupakan bagian dalam diri yang mempengaruhi stres kuliah. 


\section{Pengaruh Efikasi Diri terhadap Stres Kuliah}

Nilai signifikansi t untuk variabel Efikasi diri sebesar 0,012. Efikasi diri yang mencakup keyakinan individu terhadap kemampuan yang dimilikinya untuk memobilitasi motivasi, sumber daya berpengaruh terhadap stres kuliah.

\section{SIMPULAN, KETERBATASAN, DAN SARAN}

Berdasar analisis yang telah dilakukan, maka dapat disimpulkan bahwa persamaan regresi linier berganda menunjukkan perilaku belajar, kecerdasan emosional dan efikasi diri mahasiswa jurusan akuntansi, memberikan pengaruh terhadap stres kuliah responden. Hasil uji t menunjukkan bahwa variabel perilaku belajar, variabel kecerdasan emosional, dan variabel efikasi diri berpengaruh terhadap stres kuliah.

Keterbatasan dalam penelitian ini adalah data penelitian hanya pada universitas, sedangkan perguruan tinggi yang tidak menggunakan nama universitas tidak diambil sampel. Pengambilan sampel pada penelitian ini hanya pada 12 universitas yang ada di D.I.Yogyakarta. Hal tersebut dikarenakan ada beberapa universitas yang tidak mencukupi kuota mahasiswa akuntansi untuk bisa diambil sampel. Selain itu, beberapa universitas ada yang tidak mengijinkan dilakukan penelitan pada universitas tersebut.

Berdasar keterbatasan yang ada, saran untuk penelitian selanjutnya adalah menambahkan variabel-variabel aspek individual lainnya, aspek organisasional dan lingkungan, maupun menambahkan variabel intervening atau moderating, serta menambahkan jumlah responden untuk penelitian. Selain itu, diharapkan juga membuat pertanyaan yang lebih valid untuk pengujian menggunakan analisis faktor. Selain perilaku belajar dan kecerdasan emosional, efikasi diri seseorang juga memiliki kecerdasan spiritual atau Spiritual Quetient (SQ), Oleh karena itu, penelitian mendatang dapat mengembangkan penelitian dengan menambahkan kecerdasan spiritual sebagai variabel independen. 


\section{DAFTAR PUSTAKA}

Astuti, Dian Puji. 2011. Pengaruh Perilaku Belajar, Kecerdasan Emosional, dan Kecerdasan Spiritual terhadap Stres Kuliah Mahasiswa Akuntansi di Universitas Ahmad Dahlan Yogyakarta. Skripsi Fakultas Ekonomi Universitas Ahmad Dahlan Yogyakarta.

Ariyanti, Ika M P. 2005. Pengaruh Kecerdasan Emosional Mahasiswa Akuntansi terhadap Stres Kuliah, Fakultas Ekonomi, UPN "Veteran”, Yogyakarta.

Azizah, Nur Rizkia. 2011. Hubungan Efikasi Diri dengan Minat Kewirausahaan pada Mahasiswa Fakultas Ekonomi Uin Maulana Malik Ibrahim Malang. Jurnal Fakultas Psikologi Universitas Islam Negeri Maulana Malik Ibrahim Malang.

Bulo, William. 2002. Pengaruh Tingkat Pendidikan Tinggi terhadap Kecerdasan Emosional, Jurnal Fakultas Ekonomi, Universitas Gadjah Mada, Yogyakarta.

Cooper, R.K dan Sawaf A. 1998. Executive EQ: Kecerdasan Emosional dalam Kepemimpinan Organisasi. (Terjemahan T. Hermaya), Jakarta: PT. Gramedia Pustaka Utama.

Farida, Hanik. 2006. Pengaruh Kompetensi Utama Kecerdasan Emosional dan Self-Efficacy terhadap Kenyamanan Supervisor dalam Melakukan Penilaian Kinerja (Studi pada PT.Bank Negara Indonesia Persero Tbk kantor cabang di Karesidenan Surakarta). Fakultas Ekonomi Universitas Sebelas Maret.

Goleman, Daniel. 2003. Working With Emotional Intelegence. (Terjemahan Alex Tri Kantjono W) Jakarta: PT Gramedia Pustaka Utama.

Greenberg, J.S. 2002. Comperehensive Stress Management. 7th ed. New York: McGraw-Hill Companies, inc.

Ghozali, Imam. 2006. Aplikasi Analisis Multivariate dengan Program SPSS. Semarang. Badan Penerbit Universitas Diponegoro.

Gujarati, Damodar. 2006. Dasar-Dasar Ekonometrika.Jakarta: Erlangga.

Hanifah, Syukriy Abdullah (2001). Pengaruh Perilaku Belajar terhadap Prestasi 104 
Akademik Mahasiswa Akuntansi. Media Riset Akuntansi, Auditing dan Informasi, Volume 1, No. 3, 63-86.

Indriantoro, Nur dan Bambang Supomo. 1998. Metodologi Penelitian Bisnis untuk Akuntansi dan Manajemen. Edisi Pertama. Yogyakarta : BPFE. UGM.

Marita, Sri Suryaningsum, Hening Naafi Shaalih. 2007, Kajian Empiris atas Perilaku Belajar dan Kecerdasan Emosional dalam Mempengaruhi Stres Kuliah Mahasiswa Akuntansi.

Patmasari, Lia. 2012. Pengaruh Perilaku Belajar, Kecerdasan Emosional, Kecerdasan Spiritual dan Efikasi Diri terhadap Stres Kuliah Mahasiswa Akuntansi (Studi Empiris Pada Mahasiswa Universitas Ahmad Dahlan Yogyakarta). Skripsi Fakultas Ekonomi Universitas Ahmad Dahlan.

Pramono. 2012. Kajian Empiris atas Perilaku Belajar dan Kecerdasan Emosional dalam Mempengaruhi Stres Kuliah Mahasiswa Akuntansi Studi Kasus pada Universitas Sebelas Maret dan Universitas Muhammadiyah Surakarta. Universitas Muhammmadiyah Surakarta.

Saryanti, Endang. 2010. Kajian Empiris Perilaku Belajar, Efikasi Diri dan Kecerdasan Emosional yang Berpengaruh pada Stres Kuliah Mahasiswa Akuntansi pada Perguruan Tinggi Swasta di Surakarta. Jurnal Fakultas Ekonomi STIE AUB Surakarta.

Stiaji, Widi Indra. 2011. Pengaruh Perilaku Belajar Dan Kecerdasan Emosional Terhadap Stres Kuliah Mahasiswa Akuntansi. (Studi Kasus: Mahasiswa Akuntansi Universitas Pembangunan Nasional "Veteran".

Sujarweni, V. Wiratna. 2007. Belajar Mudah SPSS untuk Penelitaian Skripsi, Desertasi dan Umum. Yogyakarta: Ardana Media.

Sugiyono. 2011. Metode Penelitian Pendidikan (Pendekatan Kuantitatif, Kualitatif dan R\&D), Bandung: ALFABETA.

Suwardjono. 1991. Perilaku Belajar di Perguruan Tinggi, www.suwardjono.com. Diakses pada tanggal 3 Desember 2012.

Tim Penyusun Kamus Pusat Bahasa. 2002. Kamus Besar Bahasa Indonesia. Balai Pustaka, Jakarta. 
Trisnawati, Eka Indah. Suryaningsum, Sri. 2003. Pengaruh Kecerdasan Emosional Terhadap Tingkat Pemahaman Akuntansi, SNA VI, Surabaya.

Yulianti.2002. Kecerdasan Emosional dan Stres Kerja, Tesis.Pascasarjana. MM UGM. 